Article

\title{
FDI and Economic Growth in Central and Eastern Europe
}

\section{Gheorghe H. Popescu}

Department of Banking and Finance, Dimitrie Cantemir Christian University, Bucharest 040042, Romania; E-Mail: popescu_ucdc@yahoo.com; Tel.: +40-72-331-3111

Received: 14 October 2014 / Accepted: 17 October 2014 / Published: 17 November 2014

\begin{abstract}
This paper discusses the major trends in scholarship about the role of FDI and exports on economic growth, the effect of tax policies on FDI, the formation of the economic catch up of the Central and Eastern Europe (CEE) region and the determinants of FDI inflows in CEE nations. I am specifically interested in how previous research investigated the influence of FDI on host country economic growth, the inward FDI stock as a percentage of GDP, the features and restrictions of fiscal schemes in CEE economies and the institutional soundness displayed in policies towards FDI. The analysis presented in this paper contributes to research on FDI as a mechanism in the transition to the market, the dissimilarities in the FDI-assisted development methods among the CEE nations, the impact of FDI inflows for productivity convergence in $\mathrm{CEE}$ and the current slowing of growth in emerging Europe.
\end{abstract}

Keywords: FDI; economic growth; Central and Eastern Europe

\section{Introduction}

Applying new conceptual and methodological approaches, this study advances to the next level the research on the organizational conduct in foreign direct investment (FDI) transactions, the reason for the Central and Eastern Europe (CEE) countries' outward FDI, the role of FDI in the catching-up process of transition countries and the connection between productivity and FDI in the CEE region. This research makes conceptual and methodological contributions to the institutional features of the drivers of FDI inflows, locational determinants of FDI, the association between increasing FDI stock and the growth of real GDP and the powerful effect of macroeconomic circumstances in the Eurozone on FDI flows to CEE economies. The theory that I shall seek to elaborate here puts considerable emphasis on the role of FDI in transition countries, the advantages related to FDI inflows, the growth potential of the CEE region and the link between Regional integration (RI) and FDI in developing economies. The literature on the role of FDI in affecting establishment performance [1], the drivers of FDI inflows in the CEE nations, 
the influence of FDI on economic growth in the CEE and transition results in the CEE transforming countries is relevant to this discussion.

\section{The Drivers of FDI Inflows in the CEE Economies}

The role of FDI as a compound collection of capital stocks, know-how and technology is a growth-enhancing component in Central and Eastern Europe (CEE) countries. FDI reinforces insufficient domestic funds to finance both ownership alteration and capital composition. FDI, as sound long-term capital inflow, may introduce technology, managerial know-how and skills required for restructuring companies. Exports and lagged FDI have a relevant positive impact on the country' economic growth. Inward FDI into the CEE countries was stimulated by a general increased economic context. The expectation of attracting FDI generated the enhancements in governance [2]. A sound macroeconomic environment, typified by low inflation, determines more FDI inflows. The relevant quality of infrastructure does not influence the attractiveness of FDI in the CEE countries. Competitiveness proxied by the modification in the unit labor cost impacts in a notable manner the entry of FDI. Relatively low unit labor costs are the chief motivator of vertical FDI by multinational firms. Openness proxied by the proportion of exports in GDP has an outstanding positive influence on the net inflows of FDI. The Eurozone business cycle has a positive and statistically important impact on FDI inflows. In the long-term, both the wide-ranging privatization index and the banking reform index have a positive and considerable consequence on net FDI inflows in CEE economies [3]. Potential European Union (EU) membership may be a substantial driver of FDI. FDI is established by the trade-off between the benefits of proximity and concentration. The economies of the CEE countries constitute a valuable laboratory to examine theories about the drivers of FDI. FDI between developed Western and transition economies is influenced by unit labor costs, host and source nation dimensions and vicinity. A declaration about calendars for admission to the EU enhances degrees of FDI to the possible members. If firms from abroad are similar to domestic ones, it would not be beneficial for them to enter host markets. Location benefits are significant in establishing where the company decides to manufacture its yields. Anticipated gainfulness will be more relevant if input expenditures are less important in the host economy than in the source country [4].

The function of FDI shifts with the occurrence of the international financial crisis in host and home economies. The impact of FDI changes with the features of multinational activities. Production and financial connections may justify the distinctive reactions of multinational and local corporations. The standard positive impact of FDI on establishment functioning can arise from a self-selection propensity. The function of FDI shifts across economies with heterogeneous occurrences of the crisis. The impact of FDI changes with the establishments' dependence on outside capital. The positive consequence of FDI is more substantial in host economies more adversely influenced by the crisis. The impact of FDI diminishes with the aggregate performance of host-country economies and advances with the occurrence of the crisis [5]. FDI may be a natural component of the catching-up process of these countries and can be related to macro-financial exposures that intensified the boom-bust cycle in the CEE nations. The desirability of the CEE economies for FDI is justified by the macroeconomic, financial and institutional position of host countries and by the macroeconomic improvements in the Eurozone. The 2007 international financial crisis and the 2011 Eurozone sovereign debt crisis have influenced the 
improvements in FDI and GDP (the positive implication of FDI on economic growth has been cut down in the wake of both crises). FDI inflows lead in a positive and statistically relevant manner [6] to economic growth. FDI can enhance the technical advance in the host economy through efficiency "spillovers". The catching-up process in CEE nations has corresponded with substantial inflows of FDI by transnational companies. The recession and the credit crunch that derived from the crisis were matched with a sharp downturn of capital inflows [3]. Investment regulations may include rules on the analysis and safety of FDI leading to an advantageous investment environment. Regional trade agreements (RTAs) can moderate horizontal (tariff-jumping) intraregional FDI. The elimination of intraregional tariffs may stimulate vertically-motivated intraregional FDI. The impacts of an RTA on extra-regional vertical (or efficiency-seeking) FDI tend to be irrelevant. The rules of origin eliminate internal trade obstacles and can influence setting judgments for FDI. Regional organizations can decide to match fiscal and monetary schemes. A common currency gets rid of intra-regional exchange-rate variability [7] (Table 1).

Table 1. FDI in 11 Central and Eastern Europe (CEE) countries (2013).

\begin{tabular}{ccc}
\hline Country & Inflow EUR million & FDI net EUR million \\
\hline Bulgaria & 1092 & 957 \\
Croatia & 437 & 578 \\
Czech Republic & 3760 & 1278 \\
Estonia & 715 & 447 \\
Hungary & 2317 & 615 \\
Latvia & 609 & 349 \\
Lithuania & 400 & 324 \\
Poland & 728 & -890 \\
Romania & 2725 & 2635 \\
Slovakia & 445 & 763 \\
Slovenia & -511 & -555 \\
\hline
\end{tabular}

Source: Wiiw Databases incorporating national and Eurostat statistics, May 2014.

As a result of the EU integration process, all CEE economies have accomplished profound financial and trade integration. Many nations became progressively vulnerable prior to the crisis, undergoing massive credit, housing and consumption expansions. In emerging economies, the lower price of non-tradables increases the proportion of tradables in GDP. Capital flows into the CEE economies took the pattern of FDI, portfolio investments and loans (the inflow of FDI was an essential determinant of economic growth in the CEE area). Total inflows to CEE were unusually substantial prior to the recent crisis. Capital inflows utilized the economic growth capacity of the CEE nations. Credit increase was a vital determinant of their economic growth and an important element in their exposure (credit to the private sector boosted quickly prior to the crisis in the CEE area). Both demand and supply components led to the pre-crisis credit increase. The degree of credit as a proportion of GDP persisted below the EU15 standard even at the culmination of the pre-crisis credit increase [8]. The EU has been the principal cause of FDI flows into the CEE countries. Many CEE economies took on a broad economic and political alteration with a hasty privatization process. Radical economic and political reforms caused virtually all members to experience economic recession at different levels (they underwent political uncertainty and 
economic collapse at the beginning of transition). The nations that advanced quickest in privatization could attract more FDI. CEE economies profit from technology outcomes and structural enhancement because of FDI. Openness to trade is chiefly positive and significantly matched with FDI inflows. Less regulatory limitations and trade obstacles are likely to further global trade and support FDI flows. FDI into CEE economies is preponderantly horizontal, with a concern for market pervasion. A low degree of skilled labor curbs FDI inflows, indicating the relevance of labor quality in affecting CEE economies' FDI inflows. The host country's market magnitude, trade setting and its labor quality impact FDI flows substantially. FDI into emerging countries may advance the performance of production networks [9] (Table 2).

Table 2. Growth of real GDP, domestic demand, exports and private consumption (2014).

\begin{tabular}{ccccc}
\hline Country & $\begin{array}{c}\text { Real GDP } \\
\text { Growth (\%) }\end{array}$ & $\begin{array}{c}\text { Real Domestic } \\
\text { Demand Growth (\%) }\end{array}$ & $\begin{array}{c}\text { Real Exports Growth } \\
\text { (Goods and Services) (\%) }\end{array}$ & $\begin{array}{c}\text { Real Private } \\
\text { Consumption Growth (\%) }\end{array}$ \\
\hline Bulgaria & 1.6 & 0.7 & 6.9 & 0.3 \\
Croatia & -0.6 & -1.5 & 0.5 & -0.6 \\
Czech & & & & 1.2 \\
Republic & 1.9 & 1.3 & 4.1 & 4.2 \\
Estonia & 2.4 & 3.9 & 4.7 & 0.7 \\
Hungary & 2.0 & 1.8 & 5.6 & 5.2 \\
Latvia & 3.8 & 4.6 & 3.1 & 3.2 \\
Lithuania & 3.3 & 4.0 & 5.7 & 2.3 \\
Poland & 3.1 & 2.6 & 6.7 & 2.1 \\
Romania & 2.2 & 1.5 & 5.7 & 1.2 \\
Slovakia & 2.3 & 1.4 & 4.8 & -0.9 \\
Slovenia & 0.3 & -1.5 & 4.2 & \\
\hline
\end{tabular}

Source: IMF, World Economic Outlook database.

Since the global economic crisis, GDP growth in most CEE countries has been lowered. All of the CEE countries underwent an expansion before the crisis. The crisis revealed important vulnerabilities in the CEE growth policy. The CEE area may be affected by external forces that influence investment flows on account of inadequate domestic savings. The CEE nations have rather strong balance sheets and have advanced a globally aggressive outsourcing and offshoring (O\&O) industry. Shifting into more knowledge-intensive manufacturing roles, moving the $\mathrm{O} \& \mathrm{O}$ industry to the next position and developing into a regional hub for agribusiness and food processing are crucial chances for CEE countries to increase both the amount and value of exports. FDI in CEE economies dropped significantly after the financial crisis. The CEE economies can enlarge their marketing endeavors by setting up more export backing bases around the globe and can bring about a larger reserve of domestic savings to finance investment and growth. They should undertake the particular obstacles to growth in their countries and take on approaches that function on a regional foundation [10]. CEE economies have accumulated striking productivity gains and huge inflows of FDI, furthered by supportive government schemes. If FDI has a persistent positive effect on productivity, nations should go on to follow policies focused on attracting FDI. Foreign capital, in the pattern of FDI inflows, has a significant function in explicating productivity growth. The impact of FDI on productivity is expanding with a declining productivity disparity in 
relation to the Eurozone. FDI and absorptive capacity are essential components for productivity convergence in CEE (establishing advantageous circumstances for FDI tends to promote productivity convergence). The favorable effect of FDI on productivity can be fortified by enhancing the absorptive strength of the recipient country [11].

FDI flows are non-debt-determining, being a desirable process of financing external present account deficits. FDI can determine the potentially volatile balance of payment flows. The advantages of FDI are likely to considerably override its costs for host economies. The case for FDI is convincing in transition countries: they are well positioned to gain from the technology and knowledge shift related to FDI. Attracting FDI is an important matter in the policy program in transition countries. Horizontal FDI (HFDI) is market-seeking investment, focused mainly on the domestic market in the host economy, whereas vertical FDI (VFDI) is cost-minimizing investment (market magnitude, trade limitations and transport expenditures can have various impacts on HFDI and VFDI). FDI associated with using plentiful natural resources may not lend itself to classification into these types of FDI. Gravity elements (market magnitude and vicinity to the source economy) are the most relevant drivers of FDI [12]. FDI to the Balkans is determined by geographical and institutional circumstances, and FDI degrees might be influenced by the chances for EU membership. FDI has had a more significant function in the Balkan area than in the CEE and Baltic economies. FDI to the Balkan nations can be further enhanced by government schemes. Western Balkan countries should raise their FDI for the purpose of intensifying alterations and decreasing unemployment to compete for EU membership. The return of substantial amounts of FDI is improbable in the short term. Intra-regional portions in FDI have not been modified significantly since the 1990s. The sectoral allocation of FDI has been distinct across the transition areas. The distance between host and home economy may have been an outstanding driver of FDI. Market-seeking FDI is determined by the magnitude and growth of the host country market [13].

FDI is investment made by a firm in the investor economy in a foreign, host nation [14], applying to business transactions and striving to achieve a permanent interest and an active function in a host corporation. The wellbeing and the soundness of the economy have a positive impact on FDI. FDI is a vital environment through which national economies are interrelated on an international basis (there is exponential growth in the strength of planetary exchanges) and is a result of an investor's evaluation of risk and return to calculate the investment that generates the most relevant profit. Investors' and hosts' performances have a significant function in forming FDI. The CEE nations should be greatly implicated in building FDI markets by institutionalizing exchanges with foreigners as suitable economic conduct and form FDI flows by debating liberalization constraints from the global setting with protectionist domestic concerns grounded in a nationalist position [15].

\section{The Consequences of FDI on Economic Growth in the CEE}

The decreased amount of limitations on investment in a market and the absence of corruption are related to substantial net FDI inflows. Portfolio flows, bank lending and FDI have generated the boom-bust cycle and correlated inequalities in the CEE economies. The macroeconomic circumstances in the Eurozone influence the desirability of FDI inflows. Net FDI inflows determined, in a positive and statistically relevant manner, economic growth between 1993 and 2013. Host economies from CEE could go on to stimulate the entry of FDI flows. A sound macroeconomic environment, labor 
expenditures that expand in line with productivity and an improved infrastructure are prerequisites for future FDI inflows. CEE should not go back to a growth pattern immoderately reliant on capital inflows [3]. FDI is stimulated if the trade policy of the host country is liberal and because multinational companies have a more substantial tendency to export. EU accession provides corporations situated in present EU member countries the chance to move production to economies with lower labor expenditures. Satisfying the demands for admission entails an external certification of the status of economic management and institutional advancement. FDI flows are more substantial for settings with lower unit labor expenditures, irrespective of distance or host country magnitude. Investing firms tend to depend on their own resources and capital markets in their home economies for financial resources. Nations having more significant trading shares with EU economies collect considerably more FDI.

FDI flows to the transition countries are not affected remarkably by market assessments of country-specific risk [4]. The impact of FDI is positively reliant on the circumstances of home-country economies, involving both the evaluated degree of functioning and alterations in credit ratings. The function of FDI diverges with production connections between establishments and their foreign parent companies. The role of vertical production links is relevant in host economies that underwent a more significant occurrence of the crisis. The impact of multinational networks diminishes in the functioning of host countries and rises in the occurrence of a crisis. The function of FDI diverges considerably with the occurrence of the crisis in host and home economies. The influence of FDI varies with production connections between foreign establishments and head offices and the magnitude of financial restrictions [5].

The growth of CEE countries is mainly established on external financing. FDI has an essential function in the improvement and structural restoration of the CEE countries. CEE economies' significant reliance on external financing and the resulting financial inequalities are the main elements behind their relevant vulnerability to the external shock constituted by the crisis. There is a rise at the international level in the proportion of vertical FDI, attracted by low production expenditures. Manufacturing has a more notable function in investment flows towards CEE than it does on the international level. FDI establishes producer-driven networks significantly [16]. FDI inflows decreased alongside other kinds of capital flows during the crisis. The overall macroeconomic, financial and institutional condition [17] of the host country is a significant driver of FDI inflows. Macroeconomic situations in the Eurozone have a notable function in justifying FDI flows to the CEE nations: FDI inflows to the region are sensitive to improvements in the Eurozone, both through trade and financial routes. Host economies from CEE could stimulate the entry of FDI flows with the purpose of supporting growth. Throughout the pre-crisis period, CEE countries attracted substantial capital inflows, augmented by privatization and expectations of EU accession. The huge size of capital flows led considerably to the increase of macro-financial exposures. Important vulnerabilities appeared in bank and household balance sheets due to the substantial portion of borrowing in foreign currencies. With regard to FDI distribution throughout sectors, the services sector was the principal recipient. FDI in the manufacturing sector was mainly justified by low input expenditures and production cost savings [3].

Regional integration (RI) can determine more extra-regional investment for a zone, but not more FDI in each individual member economy. If relocation consequences take place within an area, this may generate efficiency gains. It is essential to inspect the character of areas, with the purpose of comprehending whether RTAs influence FDI. Each regional organization or each economy in such an 
organization does not have the same strength to attract FDI (various regional organizations attract diverse amounts of FDI). The establishment of a regional organization may not generate a fair allocation across economies. Poorer nations in a regional organization may not attract less FDI. Membership in a regional organization can determine further additional regional FDI inflows. The status of economies within a regional organization counts for attracting FDI [7]. FDI entails a non-negligible set-up expenditure bringing about increasing returns to scale. FDI inflows from outsiders tend to account for the main component of FDI (developing economies carry irrelevant outward FDI themselves). The market magnitude impact applies mainly to market-seeking FDI. Concerning intra-regional FDI, the decreasing of internal tariffs is likely to cut down the stimulants for tariff-jumping FDI. Intra-regional FDI triggered by the utilization of intangible assets should not be negatively influenced by the decreasing of internal tariffs. RTAs supply the advantages of free trade within the borders of a regional organization. Even if an RTA enhances the entire degree of FDI, the boost in FDI tends to be geographically intense in the RTA members with the strongest benefit by position. Each RTA member should enhance the internal business and investment conditions to the best achievable in the area for the purpose of sharing in the FDI advantages [18] (Table 3).

Table 3. Consumer Price Index (CPI) inflation, current account balance and external debt (2014).

\begin{tabular}{ccccc}
\hline Country & $\begin{array}{c}\text { CPI Inflation } \\
\text { (Period Average) } \mathbf{( \% )}\end{array}$ & $\begin{array}{c}\text { CPI Inflation } \\
\text { (End of Period) (\%) }\end{array}$ & $\begin{array}{c}\text { Current Account } \\
\text { Balance to GDP (\%) }\end{array}$ & $\begin{array}{c}\text { Total External } \\
\text { Debt to GDP (\%) }\end{array}$ \\
\hline Bulgaria & -0.4 & 0.5 & -0.4 & 95.1 \\
Croatia & 0.5 & 1.0 & 1.5 & 98.1 \\
Czech & & & -0.5 & 51.7 \\
Republic & 1.0 & 1.2 & -1.3 & 79.3 \\
Estonia & 3.2 & 2.8 & 2.7 & 114.5 \\
Hungary & 0.9 & 2.9 & -1.6 & 131.4 \\
Latvia & 1.5 & 2.4 & -0.2 & 62.4 \\
Lithuania & 1.0 & 1.7 & -2.5 & 67.6 \\
Poland & 1.5 & 2.1 & -1.7 & 61.6 \\
Romania & 2.2 & 3.5 & 2.7 & 83.0 \\
Slovakia & 0.7 & 1.6 & 6.1 & 87.1 \\
Slovenia & 1.2 & 1.3 & & \\
\hline
\end{tabular}

Source: International Monetary Fund, World Economic Outlook database.

Real exchange rate assessment during the catching-up process is a specific aspect of the CEE region's development pattern. Nominal interest rate merging and higher inflation knock down real interest rates in CEE economies. Economic growth in the CEE area depended on net private capital inflows. Substantial integration with the EU has influenced CEE nations with respect to huge capital inflows. The chances of integration with the EU have driven reform and transition processes in CEE economies. CEE countries undertook a relevant level of liberalization in external and internal economic connections. Between 2002 and 2008, all CEE nations underwent considerably more relevant growth than western European economies. The pace of technology transfer was consolidated by the securing of their economies to EU pre-accession and accession agreements. Total factor productivity (TFP) was the main element among growth drivers in CEE economies before the crisis. CEE nations were vulnerable to the 
imbalances of and shocks experienced by the international financial markets. [8] China is one of the most significant host markets for EU FDI and has undergone several stages in inward FDI from the rest of the globe. FDI into China began to switch from labor and capital concentrated to chiefly technology-based manufacturing. Both China and CEE economies regard the EU nations as their main sources of FDI inflows. Market magnitude, level of trade liberalization and labor quality are important in directing FDI setting options among CEE economies. FDI inflows to China and the CEE countries are not relevantly struggling against each other (China and CEE nations are at least loosely in the same international supply chain). Substantial growth of China's inward FDI is not a threat to CEE economies in forcing out the FDI flows into the area. China FDI inflows are not advancing to the detriment of FDI flows into CEE. There is an unsatisfactory connection between FDI into China and FDI into the CEE economies. China and the CEE nations are integral to the international production network. FDI into the CEE countries has been more affected by service sector investments than has FDI into China [9].

The CEE nations have ascended in international standings in terms of supplying outstanding conditions for business, have experienced a rather sound macroeconomic environment since EU accession and have become easier locations to do business. In the pre-crisis period, the CEE countries succeeded in maintaining growth [19] without increasing labor participation degrees (CEE nations kept labor employment rather sound). The number of hours worked influences CEE economies with respect to identifying ways to increase labor force participation. CEE industries will be under pressure to increase output with more capital investment and more relevant labor participation degrees. In the aftermath of the international financial crisis and recession, the economies of the CEE area attempted to regain their earlier growth paces. Substantial GDP growth across the CEE area was considerably reliant on consumption before the crisis. CEE consumers paid out their high incomes and counted on credit to boost consumption before the crisis. Reliance on borrowing to finance consumption left the CEE nations extremely weak when the international crisis appeared. The loss of FDI has made it more difficult for the CEE nations to finance their present account deficits [10]. The catching-up process in CEE has corresponded with substantial inflows of FDI. The magnitude of total advantages related to FDI relies on the absorptive strength of the recipient nation. FDI is an essential route for economic restructuring and global technology distribution. By combining FDI with the relative productivity degree, one can evaluate to what extent benefits from foreign capital inflows rely on the absorptive capacity. Human capital is a relevant element forming the future route of convergence in the zone [11].

The FDI inflow in the CEE countries has been a key component in the first phase of the privatization process throughout the transition period. FDI augments economic development and the level of living in CEE. The CEE nations have determined the positive consequences of FDI on the transformation process of their economies, this being the most widespread kind of capital flow for their rebuilding and improvement. The CEE economies enhanced their percentage of the entirety of EU trade. There are various models of economic growth and dissimilarities in the output performance of different CEE countries. As FDI has become the most ordinary sort of capital flow during the transition period in the CEE, the governments of the CEE economies [20] have been advancing formal FDI promotion strategies supplying relevant stimulants for foreign corporations. The EU schemes and the national motivator-based FDI policies affect the business medium in the CEE nations. [21] Trade schemes and trade expenditures have an outstanding effect on FDI flows. Regional integration diminishes HFDI and encourages VFDI. Labor skills have usually positive consequences on FDI, skill-rich economies attracting high-skill industries. 
Agglomeration impacts are most ordinarily proxied by the quality of the system, the level of development and the lagged stock of FDI. The prevalence of gravity variables among the drivers of FDI indicates that schemes can have a rather restricted effect. When shifting from below to above the limit, the assessed connection between FDI and its drivers alters. An FDI becomes quite resistant to deformities and risks once the economic and legal setting is investor friendly [12]. The CEE countries do not constitute a uniform entity with regard to magnitude and factor endowments, the macro-economic normalization process or the level to which they have established systemic improvements. CEE countries' development is grounded on the opening-up of the economy, entailing deregulation and a decrease of limitations on trade and investment flows. Outward FDI from the CEE economies tends to be further stimulated by EU membership. FDI into and from the CEE nations is interconnected with the process of integration into the EU. External and macro-organizational elements are significant drivers of FDI flows [22].

The magnitude of the economy is constituted in the gravity pattern by the GDP of the host country. The capacity to utilize market searching for opportunities is augmented by scale economies. Efficiency-seeking FDI may take the pattern of investment by companies searching for lower manufacturing expenditures. Resource seeking is a different incentive, determining transnational companies in the resource area to invest in host countries. Asset-seeking FDI is generally examined concerning tangible or intangible assets. For most transition nations, the process of privatization has constituted a separate incentive for FDI. Effective schemes to accomplish substantial scale privatization are related to enhanced FDI in the transition economy region [13]. FDI allows host economies to increase capital formation and to augment the quality of the capital stock, shifting to up-to-date technology and innovation. Inward FDI attracted by a liberal trade setting [23] may adjust to present or possible comparative benefits in trade. The positive impacts of FDI tend to boost with the growing degree of regional capabilities and rivalry. Lagged FDI has a notable positive influence on country' economic growth, being a relevant expository variable for growth in transition countries. Spillover effects from FDI regarding know-how and technology effect the time of appearance. Lagged GDP growth puts forth a substantial impact on present GDP growth [2].

The investment flows are formed by the host country's economic and political features and are transmitted through the current network of social connections between nations. Investors and hosts will carry out FDI transactions if they count on social agencies and act pragmatically. FDI business in unstable times may or may not generate profit maximization. In the case of FDI in CEE, resolutions could be characterized by value rationality. Determining the paths of FDI flows in the CEE countries provides an outstanding occasion [24] to inspect the progress of FDI markets. FDI has generated relevant FDI stock when analyzed with regard to the magnitude of the CEE economies. Clarifying the drivers of FDI is important for comprehending their economic change. There are significant cross-national alterations in FDI flows [15]. CEE nations have a notable capacity for economic growth because of unsaturated markets and a relevant level of FDI desirability due to the geopolitical significance of the region. The CEE economies are geopolitically relevant partners and encouraging cost-efficient production settlement for EU firms. Global trade and FDI are accompaniments in the CEE countries. The trade openness variable may clarify the function of trade in FDI inflows, being a relevant proxy for the level of internationalization. The positive impacts of FDI on trade are more numerous than the negative ones. GDP magnitude and openness have positive and statistically outstanding effects on total 
FDI inflows in the CEE economies. Improvements that broaden political rights and civil liberties may enhance the amount of total FDI inflows in the CEE countries. Institutional variables affect FDI inflows in the CEE economies, besides GDP magnitude and trade openness [25].

\section{Transition Outcomes in the CEE Transforming Economies}

The transition economies may attract FDI inflows regardless of their estimated degree of sovereign default risk. Foreign direct investors tend to be affected by the soundness of the intrinsic business setting. FDI levels are associated positively with host and source GDP and connected negatively with distance and unit labor expenditures. EU declarations about possible accession have outstanding separate impacts on FDI flows to transition economies. EU companies aim lower labor expenditures and identify rather low transaction costs in handling production facilities [26] over a short distance. Economies that have carried out transition schemes successfully are guaranteed rather swift EU membership [4]. Producer-driven-network FDI has essentially altered the economic and export configuration of the CEE nations. Export capacities in CEE settings are bolstered in large measure through FDI and resettlement. Manufacturing FDI in CEE chiefly aims for efficiency and increasing exports. CEE economies do not have an obvious specialization in the value chain in regard to labor-intensive or low-skill undertakings. Western transnational firms profit from inexpensive sourcing from CEE settings, fortifying their market statuses and competitiveness at the international level. Government debt is considerably diminished for most CEE nations than is commonly the case for developed countries. CEE economies have been affected severely by worldwide deleveraging and frozen cross-border bank lending [16].

After the burst of the 2007 global economic and financial crisis, the severe macroeconomic and financial adjustment process, combined with the drying-up of net FDI inflows on the financing aspect of the present account, generated significant losses in output. During 2010-2011, balance-of-payments inequalities reappeared in several CEE countries, in addition to the reaction of exterior financing in emerging Europe. CEE economies have been notably influenced by the step-up of the Eurozone sovereign debt crisis in late 2011. Between 2010 and 2013, portfolio debt flows took the place of FDI as the principal source of financing. Short-term financing circumstances in the Eurozone influence capital inflows to CEE nations. The Eurozone business cycle might impact FDI desirability. The catching-up process of the CEE economies has corresponded so far with substantial inflows of FDI. The absorptive capacity may augment the transfer of technology, beefing up the effect of FDI on productivity growth. If FDI is chiefly determined by domestic aspects, policymakers are better able to influence it [3]. FDI in developing economies is partially triggered by inexpensive labor expenditures and a decrease of production costs. Diminished import obstacles prevent tariff-jumping FDI, but may encourage vertical FDI by furthering the imports of inputs and machinery. The growth of domestic market magnitude has a positive and important influence on FDI. The RTA standard education [27] and financial soundness put forth a negative effect on the FDI acquired by the home country. Within an RTA, FDI may choose establishment in an economy with a significant labor supply. The RTA nations should align domestic business requirements with the best achievable in the zone for the purpose of protecting their proportion of the FDI advantages (the setting up of a zonal market may encourage fair rivalry between the partner economies). The institution of a RTA, by expanding the market magnitude of individual countries, is inclined to encourage the inflow of FDI. If an RTA is to be brought about, each member country should 
bring the feature of its business context to the best attainable one in the region in order to share in the FDI advantages [18].

Grave external account instabilities and processes of credit expansion made CEE countries liable to contagion results. The crisis has generated relevant boosts in public debt in CEE economies. The pre-crisis boom was determined by a too-rapid credit spread associated with foreign capital inflows that sustained wage and price rises. Before the crisis, most CEE nations underwent fiscal deficits, but they were not notable enough to generate rising public debt. The single market, EU transfers and the securing of schemes to EU norms had crucial functions in the growth process. The embracing of either hard pegs or elastic exchange rate systems and the loss of transitional regimes typify CEE economies. Most of them have adequate funds to assist with the progressive rectification of the exchange rate. The necessity to diminish currency substitution must be evaluated weighing the particular aspects of CEE countries. CEE economies stand to profit from the badly required extreme reform [28] of the regulation and supervision of financial markets [8]. The CEE nations should advance domestic sources of investment capital and try to restore FDI flows. The massive inflows of FDI prior to the crisis obscured rather unsatisfactory degrees of domestic saving in CEE countries. They also had a relatively low rate of fixed investment. Policy makers in the CEE region can correlate and together formulate schemes to engage foreign investors in specific industries. Going up the value chain in knowledge-intensive manufacturing is a prime concern for CEE countries. To advance attracting FDI in knowledge-intensive economies, CEE policy makers should liberalize their markets [12] and cut down regulatory intricacy. The largest portion of CEE outsourcing and offshoring being undertaken is business process activity and can profit from near-shoring. CEE outsourcing and offshoring firms should take on high-skill undertakings at their settings [29] and administer lower-level processes in locations with lower labor expenditures. The CEE countries can concentrate on the productivity matters in economies that have lagged behind in productivity enhancements and should turn to hurdles to growth that effect industries and sectors [10].

The private investment from the EU economies constitutes the most relevant portion of productive strength possessed by foreigners in the CEE. They have augmented the business setting and initiated policy decisions focused on liberalizing their economies. The FDI inflow in transition CEE nations represents a significant percentage of GDP. Foreign capital has an essential function in CEE economies, being an outstanding sign of the globalization process in the region. The FDI is proven in the more substantial export from the CEE. Inward FDI stock leads to economic growth in the CEE, representing a vital determinant that encourages sustained economic growth (there is a positive correspondence between FDI inflows and economic growth). Inward FDI assists in boosting capital stock in the host country, advancing productivity and the pace of economic growth. The FDI as correlated to other inputs, such as labor, domestic capital and export, has a notable effect on GDP growth [21]. A liberal foreign exchange and trade scheme and progressive reforms in the infrastructure area stimulate FDI. Endeavors to upgrade governance and withstand corruption may not influence FDI directly, but could encourage foreign investment indirectly via their positive impacts on the economy. Nations can attract FDI above their capacity by embracing more FDI-friendly schemes than their rivals. The CEE economies can expect to attract important supplementary FDI if they enhance their schemes. The character of FDI alters as the host nation attracts more foreign investment [12]. FDI stocks are a more significant proxy than flows for the extent of global production. The CEE countries have lately been developed as outstanding host and home 
economies for FDI. There are obvious dissimilarities among the CEE countries, indicating the difference in the degree of development and/or desirability to foreign investors. As outward investors, the CEE nations are heterogeneous. The growth of inward FDI is declining on account of the steady reduction of privatization-related FDI. Advancing unit labor expenditures influence both inward and outward FDI flows. There is a causal link between an economy's FDI type and its degree of development [22] (Table 4).

Table 4. Most attractive countries to establish operations (CEE, 2014).

\begin{tabular}{cc}
\hline Country & Percent \\
\hline Poland & $31 \%$ \\
Czech Republic & $11 \%$ \\
Romania & $9 \%$ \\
Hungary & $8 \%$ \\
Ukraine & $7 \%$ \\
Turkey & $6 \%$ \\
Latvia & $3 \%$ \\
Slovakia & $2 \%$ \\
\hline
\end{tabular}

Source: Ernst \& Young's 2014 European attractiveness survey (total respondents: 808).

Through the whole of the transition area, foreign capital has been a notable addition to domestic savings. The stock of inward FDI as a proportion of GDP is a sign of foreign capital pervasion in an economy. FDI has had a significant function in firm restructuring [25] in the transition area during privatizations. FDI has not led relevantly to advancing exports or to industrial variegation and improvement. There is more FDI in economies where institutions are more encouraging of the market. The process of joining the EU requires nations to better their institutional quality. Declaration of EU membership generates more relevant degrees of FDI [13]. FDI in CEE adjusts across economies over time, within nations by the investor's country of origin and across organizational circumstances. FDI indicates independent economic agents reacting to openly generated prices aiming at setting up utility. The nations that guarantee the most significant returns and minimum expenditures will attract the most FDI. Uniform country features are essential drivers of FDI flows. The roots of FDI must be determined in the actions of both investors and hosts and the links between them. Economic stimulants and equilibration in host nations clarify little about FDI flows to CEE countries: their attempts to institutionalize FDI make the decisive distinction. FDI flows to CEE economies indicate considerable within-country fluctuation by investor nations of origin [15]. GDP magnitude and openness variables have positive and statistically important coefficients. For FDI inflows in the primary area, both economic freedoms and trade openness [30] are economically significant factors. Investors in the manufacturing area examine GDP magnitude, trade openness and institutions [31] while investing into the CEE countries. Pro-growth and pro-trade schemes would improve FDI inflows into the CEE economies, who should formulate their own national FDI policies by investigating their own strengths and weaknesses in various areas of their economies. Schemes and reforms that advance economic integration with the EU countries would assist in raising FDI inflows into the CEE nations. Policy-makers should enhance institutions and give a high priority to institutional improvements that can augment FDI inflows to a more relevant extent [25]. 


\section{Conclusions}

Research on the role of institutions as a component that influences FDI inflows in the CEE economies, the CEE nations' FDI assisted-development paths, the role of absorptive capacity in establishing the effect of FDI on productivity growth and FDI impacts in CEE transition countries has yielded fairly consistent findings over the past decade. The paper generates insights into the significance of trade and FDI for the economic growth of CEE nations, the influence of FDI on productivity growth, the features of financial intermediation in the CEE region and the effect of financial and capital limitations on FDI. These findings highlight the importance of examining the relational character of FDI, the prevalence of gravity components in regulating FDI flows, the impressive growth of CEE countries preceding the global financial crisis and the incorporation of the CEE nations into the world economy through trade and capital flows. The current study has extended past research by clarifying the link between FDI inflows and economic growth in the CEE countries, the drivers of inward FDI to CEE economies, the role of FDI in generating microeconomic performance and the effect of the global economic crisis on CEE nations.

\section{Conflicts of Interest}

The author declares no conflict of interest.

\section{References}

1. Sum, V.; Chorlian, J. Training and the firm's competitiveness: A survey of practitioners. Econ. Manag. Financ. Mark. 2014, 9, 11-26.

2. Sapienza, E. Foreign direct investment and growth in Central, Eastern and Southern Europe. Investig. Econ. 2010, LXIX, 99-138.

3. Jimborean, R.; Kelber, A. Foreign Direct Investment Drivers and Growth in Central and Eastern Europe in the Aftermath of the 2007 Global Financial Crisis; Working Paper 488; Banque de France: Paris, France, 2014.

4. Bevan, A.A.; Estrin, S. The determinants of foreign direct investment into European transition economies. J. Comp. Econ. 2004, 32, 775-787.

5. Alfaro, L.; Chen, M. Surviving the global financial crisis: Foreign ownership and establishment performance. Am. Econ. J. Econ. Policy 2012, 4, 30-55.

6. Popescu, G.H. The macroeconomic determinants of migrant remittance flows. Econ. Manag. Financ. Mark. 2014, 9, 121-126.

7. Te Velde, D.W.; Bezemer, D. Regional integration and foreign direct investment in developing countries. Trans. Corp. 2006, 15, 41-70.

8. Becker, T.; Daianu, D.; Darvas, Z.; Gligorov, V.; Landesmann, M.; Petrovic, P.; Pisani-Ferry, J.; Rosati, D.; Sapir, A.; Di Mauro, B.W. Whither Growth in Central and Eastern Europe? Policy Lessons for an Integrated Europe; Bruegel: Brussels, Belgium, 2010; Volume XI.

9. Fung, K.C.; Korhonen, I.; Li, K.; Ng, F. China and Central and Eastern European countries: Regional networks, global supply chain or international competitors? J. Econ. Integr. 2009, 24, 476-504. 
10. Labaye, E.; Sjatil, P.E.; Bogdan, W.; Novak, J.; Mischke, J.; Fruk, M.; Ionutiu, O. A New Dawn: Reigniting Growth in Central and Eastern Europe; McKinsey Global Institute: New York, NY, USA, 2013.

11. Bijsterbosch, M.; Kolasa, M. FDI and productivity convergence in Central and Eastern Europe: An industry-level investigation. Rev. World Econ. 2010, 145, 689-712.

12. Demekas, D.G.; Horvath, B.; Ribakova, E.; Wu, Y. Foreign direct investment in European transition economies-The role of policies. J. Comp. Econ. 2007, 35, 369-386.

13. Estrin, S.; Uvalic, M. FDI into transition economies. Econ. Transit. 2014, 22, 281-312.

14. Sum, V. Effects of business and consumer confidence on stock market returns: Cross-sectional evidence. Econ. Manag. Financ. Mark. 2014, 9, 21-25.

15. Bandelj, N. From Communists to Foreign Capitalists; Princeton University Press: Princeton, NJ, USA, 2007.

16. Galgóczi, B. Boom and bust in Central and Eastern Europe: Lessons on the sustainability of an externally financed growth model. J. Contemp. Eur. Res. 2009, 5, 614-625.

17. Nica, E. The development of transformational leadership. J. Self-Gov. Manag. Econ. 2014, 2, $26-31$.

18. Jaumotte, F. Foreign Direct Investment and Regional Trade Agreements: The Market Size Effect Revisited; Working Paper 206; International Monetary Fund: Washington, DC, USA, 2004.

19. Koplyay, T.; Lloyd, D.; Mako, C. HR issues evolution along the market lifecycle and the value chain: Case of the hi-tech industry. Psychosociol. Issues Hum. Resour. Manag. 2014, 2, 7-33.

20. De Beaufort, V.; Summers, L. Women on boards: Sharing a rigorous vision of the functioning of boards, demanding a new model of corporate governance. J. Res. Gender Stud. 2014, 4, 101-140.

21. Kornecki, L.; Raghavan, V. Inward FDI stock and growth in Central and Eastern Europe. Rev. Econ. Financ. 2011, 1, 19-30.

22. Boudier-Bensebaa, F. FDI-assisted development in the light of the investment development path paradigm: Evidence from Central and Eastern European countries. Trans. Corp. 2008, 17, 37-67.

23. Dan, S. Welfare and work: How and how much do TANF cash benefits affect the labor supply of single parents? Psychosociol. Issues Hum. Resour. Manag. 2014, 2, 34-50.

24. Nica, E. Corporate practices in higher education. Psychosociol. Issues Hum. Resour. Manag. 2014, 2, 51-56.

25. Tintin, C. The determinants of foreign direct investment inflows in the Central and Eastern European countries: The importance of institutions. Communist Post-Communist Stud. 2013, 46, 287-298.

26. Popescu Ljungholm, D. The performance effects of transformational leadership in public administration. Contemp. Read. Law Soc. Justice 2014, 6, 110-115.

27. Lazaroiu, G. Besley on Foucault's discourse of education. Educ. Philos. Theory 2013, 45, 821-832.

28. Popescu, G.H. Unemployment dynamics in the U.S. J. Self-Gov. Manag. Econ. 2014, 2, 32-37.

29. Popescu Ljungholm, D. Transformational leadership behavior in public sector organizations. Contemp. Read. Law Soc. Justice 2014, 6, 76-81.

30. Inglehart, R.F.; Borinskaya, S.; Cotter, A.; Harro, J.; Inglehart, R.C.; Ponarin, E.; Welzel, C. Genetic factors, cultural predispositions, happiness and gender equality. J. Res. Gender Stud. 2014, $4,32-100$. 
31. Bensman, D. Misclassification: Workers in the borderland. J. Self-Gov. Manag. Econ. 2014, 2, 7-25.

(C) 2014 by the authors; licensee MDPI, Basel, Switzerland. This article is an open access article distributed under the terms and conditions of the Creative Commons Attribution license (http://creativecommons.org/licenses/by/4.0/). 